Article

\title{
Deconversion, Sport, and Rehabilitative Hope
}

\author{
Terry Shoemaker
}

School of Historical, Philosophical and Religious Studies, Arizona State University, 975 S Myrtle Ave \#4302, Tempe, AZ 85281, USA; terry.shoemaker@asu.edu

Received: 8 May 2019; Accepted: 22 May 2019; Published: 27 May 2019

\begin{abstract}
This article, based on qualitative interviews and ethnographic research, explores three types of on-the-ground rehabilitative hope supplied by sport for many post-evangelicals within the upper Bible Belt region traversing through the process of deconversion. First, sport is an often-cited space that is identified as broadening social networks, leading to initial questioning of inherited religiosity. Second, sport offers a level of amelioration of relational fissures caused by religious shifts away from evangelicalism. Last, this research indicates that post-evangelicals highly value spaces for discussions of social justice, and athletic activism offers symbolic solidarity. Thus, sport and deconversion can be intertwined for Southern post-evangelicals. In the end, I argue that the triangulation of deconversion, hope, and sport within a Southern context creates a way of understanding the changing Southern ethos and pathos demarcated by a shifting away from a conservative Protestantism historically dominant in the region.
\end{abstract}

Keywords: deconversion; sport; hope; bible belt; religion; rehabilitation

\section{Introduction}

In 2016, I began conducting ethnographic research to analyze changing forms of religiosity within the region of the United States known as the Upper South or the northern portion of what is generally referred to as the Bible Belt. The target respondents for this research were those once acculturated into conservative Protestantism, and my interview guide was built to discover patterns and themes in the lived experiences of how one socially and subjectively navigates deconversion from a pervasive host religious tradition in the South. The interview guide consisted of questions about religious upbringing, factors in deciding to shift religiosity, and how people continue to socially negotiate religiosity in their present life. Although the semi-structured interview guide consisted of no questions regarding sport, I was surprised to discover that sport was introduced to the discussion by approximately $15 \%$ of the consultants of the project. ${ }^{1}$

Sport plays a special role in the Southern ethos and praxis. In a previous collaboration, Eric Bain-Selbo and I analyzed and theorized this affinity toward sports in the South (Bain-Selbo and Shoemaker 2016). Our argument focused on college football and stock car racing as a functional means for Southerners to perpetuate their regional identities and construct sacrality. In this way, we proposed sport and religion competed as the primary repository for preserving the Southern heritage. In this paper, I take a slightly different approach to understanding the intersection of sport and religious deconversion in the Bible Belt through offering a finer grained portrait of the lived realities of some Southerners deconverting from conservative Protestantism (e.g., Evangelicalism, Fundamentalism, Pentecostalism). Through illuminating three ways that sport integrated into the

1 Although $15 \%$ might constitute a small percentage of the overall respondents, this number represents the number of respondents who referenced sport without any provocation. The importance of sport, as illustrated throughout this paper in the deconversion process, could be much higher had the project intentionally been investigating sport and deconversion. 
discussions of deconversion and newly forming spiritualities during that ethnographic data gathering, I will argue that sport can offer a rehabilitative hope for familial fracturing caused by religious deconversion, a spatial opportunity in a restrictive milieu to expand one's social network, and a space to align with contemporary social issues. In each of these areas, some consultants pointed to sport as instrumentally rehabilitative in their development and perseverance. As a means of illustrating these instances, I include multiple vignettes throughout the paper. The broader relevance of this paper is to demonstrate that sport plays particularly significant roles in the lives of individuals that intersect with deconversion and to provide some research directions for future projects regarding sport and religion.

\section{Religion and the Bible Belt}

Data on religious affiliations in the United States indicate that there is an increasing trend toward Spiritual But Not Religious (SBNR), a decrease in traditional forms of religiosity, and a common practice of switching religious affiliations (Jones and Cox 2017). The dynamic nature of subjective religiosity and the numerous options that Americans have in the religious marketplace are well documented (Smith et al. 2015; Stark and Finke 2000). Yet, as Elizabeth Drescher argues, social environments must be considered when studying religious affiliations. As Drescher states, "changes in religious affiliation, while not determined by cultural factors alone, are enabled or constrained by culture" (Drescher 2016, p. 56). In some regions of the United States, like the Bible Belt, the social constraints tend to exert social, political, and religious pressures on how individuals religiously affiliate and practice. Each of these factors-fluidity, social constraints, and autonomy—-form a nexus for understanding religion in America today. The numerous religious market options available and social pressures can complicate these shifts, and this can prolong the process of religious shifting. Much of what scholarship has concentrated on is the quantifying of the shift from A to B, but there can exist several subpoints along the subjective trajectory from point $\mathrm{A}$ to $\mathrm{B}$. The moments, decisions, actions, and choices between the originating position and the landing position are the focus of this study.

Because this study seeks to analyze "phenomena not as detached things-in-themselves, but as connected things-in-the-world" (Rogers 2012, p. 10) and "the making of identities in highly heterogeneous and fast-changing social contexts" (Altglas 2014, p. 475), the initial research project assembles and analyzes multiple forms of data and sources including qualitative interviews, participant observations, and regional histories. This form of research, referred to as a bricolage, is a type of ethnographic research useful in projects in which the researcher must assemble from various resources the emergence of cultural transitions. This specific portion of the research draws heavily upon the 65 qualitative interviews conducted over two years. For this paper, these interviews were recorded, transcribed, and analyzed seeking recurring themes and patterns related to sport and religious deconversion, while also considering the conditions of the cultural milieu.

The following vignette of a consultant that I call Mark illustrates how Mark's religious shift is complicated and constrained by his social context, which has played out over time. ${ }^{2}$

\section{Vignette 1}

Mark is white, in his thirties, and identifies today as SBNR, although he still attends a progressive Christian church with his wife. Mark was proud to describe growing up in North Carolina. His family was close, and he regularly participated in his local church, attended by several of his family members including his parents and grandparents. Their conservative Protestant church cultivated shared values, rituals, and heritage for their family and supplied them a weekly gathering time to commune followed by a family meal. In his adolescence, Mark explained that he made the decision to live his life in "close proximity to the church." This decision was soteriologically and socially based.

2 To protect the identity of my consultants, I utilize aliases. In addition, the locations of some narratives have also been modified as an additional layer of anonymity. 
There came a time during college when Mark began to question his religious beliefs and values. The foundational conservative Protestant beliefs of atonement theology, scriptural inerrancy, and divine plausibility began to rapidly crumble as he studied philosophy and existentialism. Today, more than a decade into his faith deconversion, Mark still has not been able to share authentically his views on religion with his family or that he self-identifies SBNR. He explains that divulging this information to his family would be too devastating for his grandparents particularly. Instead, he, his wife, and friends meet with a small, more progressive Christian community that offers more freedom in discussing religiosity and spirituality. This permits Mark and his wife an opportunity to appease his family and remain within social expectations, but also remains a point of contention within his family because he does not attend the family church. Taking the social import of religious affiliation and participation in the South into consideration explains partially why Mark hesitates to reveal his perspectives and opinions to his family. Revealing his religious skepticism would be perceived as an equivalency of renouncing his family heritage.

In the Bible Belt region, conservative forms of Protestantism are the dominant religious affiliations (Smith et al. 2015). The varieties of Protestant denominations physically dominate the landscape with thousands of churches, private Christian schools, parachurch organizations, and signage. This is a point of pride for many Southerners, and I have heard it debated which area or Southern state composes the "buckle of the Bible Belt" or that which idealizes the Protestant dominance. Beyond affiliations and infrastructure, the religious history of the Second Great Awakening creates an imagined exceptionalism in that the divine would choose this region to begin religious revivals. In addition, Protestant churches remain heavily segregated today (Emerson and Smith 2000), and the legacy of the Civil War forms another informative layer with the "religion of the Lost Cause", slavery, and Jim Crow (Wilson 1980). Often, the proud heritage of many Southerners is located with a specific church where family lineage can be traced. Many Southerners retain the practice of attending church together on Sundays followed by a large, post-gathering meal typically held in the patriarch's home, although like the rest of the United States, religious attendance is declining (Jones 2014).

Unlike Mark's example, many of my consultants do decide to reveal their religious doubts and critiques of their home church and, more broadly, of Southern Protestantism. This leads to tremendous family and social fracturing that can be quite devastating. Many of the consultants of my project join in a movement that scholarship is now calling "Emerging Christianities" (Moody and Reed 2017; Bielo 2017). Marti and Ganiel (2014) suggest that these communities share the continual practice of deconstruction, a process of critically analyzing one's inherited cultural and religious values, forms, and practices. Philip Harrold recognizes this in his study of Emerging Christianities' online resources (Harrold 2006). He discovers that "individuation-the conscious effort to choose one's personal identity and core convictions," is at the crux of these communities (Harrold 2006, p. 79). There exist then site-specific distinctions between these communities due to the inherited acculturations that are being deconstructed. Because religiosity and spirituality are considered in flux, these communities permit a freedom in cultivating subjective spiritual or religious orientations.

These Emerging Christian communities invert Davie (1994) notion of "believing without belonging" - the idea that many people maintain religious beliefs but choose to not be part of a traditional religious community with established gathering spaces and times. Instead of "believing without belonging," my research finds that the Emerging Christian communities are spaces of "belonging without believing." Doctrines and creeds are decentered and less important. Stated otherwise, confessional assent or doctrinal alignments are not required for membership. What I discovered was that these communities in the Upper South serve as spaces for former conservative Protestants to renegotiate their religiosity and/or spirituality (the term often utilized by the research consultants).

In essence, my research argues that in the Upper South, the Emerging Christian communities provide a space for ex-conservative Protestants to reconstitute their Self, a reconstitution process that is understood as a religious practice. This religious practice extends into multiple aspects of 
individual and collective life. My project consultants utilize their communities to grapple with various forms of identities like national, regional, sexual, gender, and race and the intersectionality of these identities. The community is a central space for reforming subjectivity during deconversion, and these communities offer an in-the-moment space that rehabituates one into new norms.

Barton $(2011$, 2012) analyses of the Bible Belt argue that there exists a compulsory Christianity that is part of a more oppressive Bible Belt panopticon attempting to regulate those within its surveillance boundaries. Barton's work focuses specifically on how sexuality is surveilled within the Upper South region through the dominance of the Christian panoptic mechanisms. My research corresponds with Barton's and discovers that multiple aspects of individual identity are regulated within the region. For instance, along with heteronormativity, patriarchal and racial norms are imposed through the panoptive infrastructures. Barton's work helps in understanding why such tension is created with the continued practices of the Emerging Christianities in permitting individual subjectivities to form. This pushes not only against the religious norms but also against strongly maintained cultural practices.

My project's consultants described the rigidity and oppressiveness of the region in various terms, but almost all referenced the difficulties they have had in shifting away from the religion of their youth. For instance, one consultant describes her life in the South as a place where "you can't be yourself. You have to watch what you say. You can't be an individual. There's always someone watching and judging." Several others echoed these sentiments, and these identity shifts often result in the fracturing of familial and social ties. Furthermore, the new spirituality produces new values and political perspectives. This creates individual perspectives and practices that are often at odds with the dominant religio-political climate of the region. Also, importantly, in most of these instances, the project consultants remain in the Upper South and must still learn to navigate the Bible Belt context as religious deconverts.

Although most consultants pointed to their religious community as the primary space for the work of deconversion, some of the project consultants indicated sport serves as an important aspect of their deconversion practices and strategies. The references to sport emerged in three categories which are explored below: Early social network expansion, a safe space for continued family relationships, and alignment with athletes' social justice proclamations. In each of these areas, sport is attributed a quality of rehabilitative hope.

\section{Social Network Expansion through Sport as Rehabilitative Hope}

Sport provides many benefits for the formation of youth across America. This obviously includes physical development but also encompasses the development of self-identity and relational network formation (Bruner et al. 2017; Côté and Fraser-Thomas 2016). Many youth maintain positive perspectives of sport participation and school athletic programs (Lubans et al. 2011). This is certainly not always the case, as there are reported bullying and overtraining issues that can emerge in some instances (Meyer et al. 2015). Less analyzed are the ways in which team and individual sports provide an opportunity for participants to expand their social networks and the effects of these social network expansions.

Playing sports includes social interaction. This involves multiple layers of interactions occurring simultaneously: coaches and athletes, teammate with other team members, athletes with referees, family members with athletes, athletes and opposing team members, etc. Negative interactions like fan feuds and violence are explored typically by scholarship (Lewis 2007; Wann et al. 2017). However, the time commitments involved formally and informally with practices, games, travel, and off-field activities like player recognitions lead to opportunities for expanding social networks and developing long- and short-term relationships. Recent scholarship offers a way of thinking about informal interactions between players, but few studies aim to analyze the long-term effects of youth sport participation vis-à-vis social interactions (Erickson and Côté 2016).

As it pertains to social interactions in college sports in the American South, Eric Bain-Selbo argues that aspects of Southern fandom-i.e., tailgating, shared social identities, spectatorship, etc.—equate to 
Victor Turner's communitas (Bain-Selbo 2012, pp. 27-52). His work locates the social significance of college sports fandom as a liminal state of being that separates fans from the mundane (Bain-Selbo and Sapp 2016). Some of Bain-Selbo's fan interlocutors indicate that they feel more connected to the college football fan community than their religious community. In addition to the emotive aspects of the fan experience, many Southerners also understand sport as providing a place for masculinity to be cultivated (Dowland 2011; Miller 2002). In a modern world that many Southerners perceive as emasculating, sport offers an opportunity to demonstrate strength and ability, while reifying the traditional patriarchal roles and privilege.

Furthermore, many conservative religious communities in the South create insular social networks. These networks elevate the importance of the religious community over external forms of social engagement. Robert Putnam argues that religious communities promote healthy levels of broad volunteerism in America, except in the case of evangelicals who focus more on internal forms of volunteerism (Putnam 2000, pp. 75-77). In such cases, religion and sport are often seen as rivals competing for time and monetary commitments from congregants and/or fans (McMullin 2013). To remedy this competition, some religious communities offer their own sporting leagues. This supplies the participatory sporting demands from some congregants and reduces time spent building social networks beyond the boundaries of the church institution. Moreover, because of the maintained objective of evangelizing, many Christians perceive sports as a place to proclaim and share one's religious faith (Hoffman 2010).

To summarize, there often exists a tension between sport and religious commitments in the South. On the one hand, sport is understood as an opportunity for discipline, evangelism, and further social interactions of the religious community. On the other hand, sport can interfere with religious participation and practice.

During qualitative interviews, a vital question for the research was to locate in the consultants' viewpoint when and where the consultants first began to question their inherited religiosity. My assumption was that forms of intellectual doubt emerged as the consultants increased in educational attainment or that a particular traumatic experience provoked the religious shift. In most cases, these were the significant factors that were highlighted by the consultants. However, in some cases, sports participations, specifically basketball, in the South resulted in project consultants questioning their faith. These cases demonstrate how social interactions in sporting spaces can disrupt individual lives religiously and prompt a spiritual deconversion in a milieu that attempts to regulate religiosity. Two particular cases demonstrate how sporting interactions can be religiously disruptive.

\section{Vignette 2}

Todd "grew up hard, red clay Baptist Fundamentalist ... in an all-white, clustered fundamentalism" in Tennessee. Although as a young boy he enjoyed the certainty and homogeneity of his community, in high school, he began to question the racial norms of his church community. These questions emerged when he was exposed to different social and racial classes while playing with his local high school basketball team. After busing policies were changed in his hometown, Todd's public school's demographics significantly changed, increasing the number of people of color. During his junior year, Todd was the only white player in his basketball team. He recalls, "Because I was an athlete, I was exposed to a different social class through athletics. From traveling to play basketball to football, I encountered people that were outside the rural bubble." Reflecting back to his basketball experience as a player, he notes that it was the social interactions with his teammates that radically reoriented his outlook on individual and systemic racism, which eventuated also in his initial questioning of his religious community that was demographically an all-white community. Todd explains, "Those things began fraying at my worldviews that I'd been given. I was aware that there were big issues and that the church could be desperately wrong on those issues." 


\section{Vignette 3}

Like Todd, Lisa's upbringing was heavily tied to her church community, which was a conservative, southern Church of Christ. She and her siblings were homeschooled as a means of protecting them from secularizing influences. She recounts that her church and family constituted the overwhelming majority of her social network as a child. Lisa thinks that her current spirituality started as she questioned her faith "in layers." The initial space for this questioning was at a homeschooling basketball league with other conservative Christian youth. Her parents helped form the homeschooling league as an athletic alternative to local non-religious leagues. During this time, though, she encountered Christians who maintained differing views from her family. It was in this instance that she recognized the diversity within the Christian tradition, which created a relativizing momentum that has progressed to today. This league continued to alter her perspectives when, later in life, one of those homeschooling teammates came out as gay. Today, Lisa proudly remembers these encounters with other youth participants as significantly informative to her current spirituality.

These two examples indicate that, in some cases, social interactions with teammates can have a profound impact on subjectivity. These instances align with Peter Berger's proposal that the modern world's religiously pluralistic society relativizes subjective perspectives on religion and spirituality (Berger 2014). This relativizing, argues Berger, "becomes a permanent experience" in the modern world (3). Thus, the conditions of modernity produce lived realities that are in constant navigation of a multitude of ideas. Berger's work focuses primarily on the ways in which religious pluralism interacts with subjective religiosity, but the continual negotiation of religious pluralism extends outside of religious institutions into sporting spaces. These spaces, and the social interactions that occur, can have similar relativizing effects. Even in the South, where some conservative, religious families attempt to build insular communities, sporting interactions can disrupt the imagined insularity.

As a number of the project consultants reflect back on their deconversion, they locate the originating point connected to sport participation. Each of these consultants attributes a rehabilitative hope to sport in this way. As often is the case, the present deconversion is understood as a distinctively improved position relative to the previous religious commitments. While a portion of consultants continue to reform their Self, sport is retroactively perceived as the factor which propelled them on their current journey. Thus, sporting participation is credited with the initial decoversion move. The deconversion is understood as humanistic in the sense that human connection significantly informs decisions and life trajectories. Thus, in some cases, sport and deconversion are intertwined in forming the reconstituted Self.

\section{Family Tensions, Sport, and Rehabilitative Hope}

The importance of familial religiosity can result in both negative and positive consequences for individuals. Studies on these consequences analyze the correlations between familial religiosity and disciplinary practices (Bartkowski and Wilcox 2000), educational attainments (Danso et al. 1997), and sermon influence on familial life (Gershoff et al. 1999). In some studies, shared, familial religious practices are posited as a cohesive mechanism (Marks et al. 2017; Chelladurai et al. 2018; Dollahite and Marks 2009). In applied scholarship, social workers are recommended to be more attentive to familial religion and spiritual practices (Godina 2014).

In this study, as the journey formulates after religious deconversion, tensions tended to emerge with social networks that were essential in consultants' past. This is a common theme that manifested throughout my research. Although social network fissures can occur in dating or business practices, the most common reference to social fracturing was with parents and siblings. The following are just a small sampling of how consultants describe their relationship with their families after deconversion:

"It's a weird thing. I love my family. But how it used to be and how it is now, it's totally different ... The reason I don't like to talk about religion is because I've seen what happens 
when you talk about it. When you get to a point with evangelicals or people who hold strongly to a worldview that is so ingrained in my family they are only here, to them, this is like purgatory. When you bring up things that you don't believe in, my parents are like that's our entire identity."-Chris, twenties, Kentucky

"I'm in a closet [about spiritual identity] and I don't know how to come out to my parents ... I don't go to my parent's house right now."-Denice, fifties, North Carolina

"I hold [my parents] at arm's length. I don't tell them the details of my life."-Brandy, thirties, Kentucky

“There's just a lot that you'll never see eye to eye on. It's not worth me trying to change [my parents'] minds on anything. I don't want to do that. We just talk about surface-level topics now."-Joan, thirties, Tennessee

In some cases, relationships were completely severed, and ostracizing occurred. This prompted some consultants to relocate geographically, but in most cases the consultants attempt to maintain relationships with family members although this requires ongoing work and negotiation. My data capture the divisions as the consultants describe religious interventions, family visits intentionally planned around religious holidays, and multiple attempts to recruit them back to the host church. These moves typically result in fracturing family relationships more rather than successfully healing the fissures.

Familial tensions and the Southern ethos often produce a tacitly held agreement to privatize religious discussions for the sake of peace. In these situations, shared commitments and allegiances are sought after to replace the loss of religious connections. This is certainly true in the earlier mentioned narrative of Mark. He describes his shared commitments to college basketball as central to maintaining his family ties. The moments of shared fandom become significantly important as a safe space for familial interactions. For instance, Mark's interpersonal conflicts with his parents and grandparents are often placated through shared allegiances to the University of North Carolina basketball and football teams. Their shared fandom supplies a space for the family to temporarily bracket other tensions and enjoy a unifying cause. Mark refers to the moments of spectatorship as sacred.

\section{Vignette 4}

Like Mark, Jack's family ties, particularly his relationship with his father, suffered after he revealed that he no longer maintained his beliefs in the doctrines of their Free Will Baptist church. Growing up in the eastern part of Kentucky, the family's life centered within the religious community. Yet, as Jack's deconversion occurred, he found himself often at odds with his father in religious discussions. Jack's father continues to push Jack to return to the faith of his youth, but Jack has now relocated to Tennessee and is part of a progressive Christian community.

As Jack described his relationship with his father, it was their commitment to West Virginia University's college football team that provided a remediating space to positively connect with his dad. "Here, on this couch watching football, that's our best times now. We tend to argue about religion and definitely about politics, but college is where we can set that aside and just be father and son again."

In each of these situations, religious difference is central to the familial tensions. For Mark and Jack's family, sport remediates an intra-family religious conflict that is occurring and ongoing. There appears to be no end in sight for their religious disagreements. Scholarship posits that sport can play a significant role in remediating social conflict at macro levels (Giulianotti 2011; Majaro-Majesty 2011), yet less research analyzes how sport interferes or remediates inter-family conflict (Simmons and Greenwell 2014). Where religion previously functioned as a cohesive social space, sport now 
functions to fill that void. It is not simply the case that sport fandom is a distraction from an ongoing conflict. In Jack and Mark's experience, sport now accomplishes for their family what their previously shared religiosity did. With less shared experiences, the families tend to sacralize the shared time with sporting spectatorship and fandom. In this way, there exists a rehabilitative hope to the shared sports fandoms.

Sport displacing religion in this way should not come as a surprise. The Southern ethos prides itself on passing on a cultural heritage. The cultural heritage includes several aspects of the Southern way of life, like food culture, geographical embeddedness, sports, and religiosity. Historically, this heritage transmission has been facilitated by the rootedness and intricacies of the localized kinships and the home (Allen 1990). As more Southerners position themselves religiously distinct from their parental inheritance (Thompson 2013), it is reasonable to imagine that other aspects of that shared history would take on a more significant meaning for the families. Thus, if religion becomes less relevant as a conduit of shared meaning-making, families will seek out other shared connections, like sports fandom, to fill the voids left by a lack of common religiosity.

\section{Social Justice, Sport, and Rehabilitative Hope}

Like the first two, the third type of rehabilitative hope supplied by sport during processes of deconversion in the South is relational in nature. To briefly recap, some consultants of the research project designated team participation in sports as the initial site for religious and spiritual expansions. The social relationships cultivated on the court of basketball facilitated a broader questioning of inherited religious norms that eventuated in deconversion. As a means of maintaining relationships after the initial deconversion process, for other consultants, sport serves as a shared space for bonding and transmitting culture. The third type of hope involves the development of a different kind of morals, values, and relational alignments accompanying decoversion.

A key aspect of deconversion highlighted in the initial research study was the ways in which the consultants drastically shifted moral positions after deconversion. This included religious values, but also political reorientations. Although most of my consultants were raised in conservative, politically leaning households, a majority of consultants describe themselves today as progressive, Democrat, or Independent party-leaning. Perspectives on several issues like civil marriage, abortion, and gun control were all noted as subjects about which values have been reoriented. The modified values significantly add to familial tensions that are already existent due to deconversion. During data collection, sport also emerged as a relational space to discuss, relate, and find solidarity with others who shared similar values.

\section{Vignette 5}

Take, for instance, Kasey and Evelyn, a married couple who have journeyed on their deconversion processes together. Kasey admits that he is more orthodox, while Evelyn describes herself as more nontraditional. During their search for a religious community, the two thought that they had found a church "on our terms." Kasey explains, "We wanted the possibility of a woman in leadership, a church that cared about the environment and directed their gaze beyond themselves. We wanted a church to at least acknowledge that there are things happening in the world." Their newly discovered values modified what they sought after in a religious community.

While in Kentucky, they found a church but were quickly disgruntled when they discovered that Evelyn would not be permitted to become a member because she taught a yoga class in the community. As she describes it, her yoga class was separated from any religious connections, but the church explained that teaching yoga was at odds with their religious beliefs and practices. Evelyn thinks that the real issue was that the yoga class provides her with an expanded social circle beyond the church community. She admits, "most of my friends are not Christians. I have more in common with people of varying faiths than most 
Christians around here. I just have more in common with them." As the spiritual journey of deconversion developed for Evelyn, she discovered that the exercise of yoga provided the opportunity to connect with other similar people.

The shifts in values and political orientations push many consultants into an active political mode opposite to that of their past. Qualitative interviews for the research project occurred during the presidential campaigning and election of 2016, and several of the project consultants were politically mobilizing and marching. Many of the consultants were raised in racially segregated religious communities in the South. Many of them attended predominantly white, religious school systems. Today, a majority of the consultants are active in allying with people of color, non-heterosexuals, and other marginalized people in the Bible Belt region. I discovered in the qualitative data an attempt to repair relationships with people at the margins of the Bible Belt society. These interactions with marginalized people groups tended to disrupt previously held notions of patriotism. I described this as a shift from a civil religious nationalism to a critical patriotism. When I asked the consultants about their current values and political positions, I typically received responses that argued for transcending national identity for a more globalized understanding of human connections.

\section{Vignette 6}

Chad was born outside of the Bible Belt, but his family relocated to Tennessee when he was a small child. Quickly, Chad explains, his family joined a local Protestant group affiliated with a Pentecostal denomination. He described several religious experiences as a teenager with his religious community, but his religiosity started when he began schooling at a Bible College. It was at the college that Chad began to question the parameters and foundations of his childhood faith. Today, he is vocal about his political leanings and is active with a political mobilizing organization. As Chad posits, "The ways that I'm patriotic are in the ways that I still have the right to say, 'I am not fucking patriotic. This is absolute garbage.' That sense of freedom and those rights, that's how I'm patriotic. Otherwise, I'm about human rights, which transcends our borders." As Chad continues to explain his current political perspectives and allegiances, he aligned his positions with Colin Kaepernick's, the quarterback athlete activist who refused to stand for the national anthem at football games. As Chad explains, "I kneel in solidarity with Kaepernick. This notion drives my family absolutely crazy."

Those on the deconversion journey appear to seek out prophetic voices that articulate their sensibilities. Many consultants referenced Martin Luther King, Jr. and the Civil Rights Movement as an ideal way that religious perspectives can motivate political mobilization. Elsewhere, I have argued that political activism by athletes today constitutes a form of prophetic activity (Shoemaker 2019). Like Chad, other consultants referenced NBA athlete activism as indicative of their current political stances and directions. To be more specific, project consultants referenced athletic activism working towards improving race relations in the United States as the model for their political aspirations. When asked about current issues within the Bible Belt, a majority of consultants indicated that racial divisions and systemic racism continue to plague the region. In this way, athletic activism offers a resonating message for the project consultants. Thus, the spiritual formation during the deconversion process seeks prophetic voices outside of traditional religious institutions.

This third type of hope grounded in athlete activism potentially challenges the second. If sport is a shared space for family, politically charging the sporting spaces might reactivate the religio-political tensions that families are seeking to avoid.

\section{Conclusions: Sporting Hope and the Changing South}

During periods of deconversion from demanding types of religious commitments that are heavily tied to social networks, those deconverting might seek to find alternative spaces to cultivate their new forms of spirituality and religiosity. As might be expected, new forms of spiritual and religious 
communities emerge to fill those voids. What is less expected, and thus less examined, are the ways that other cultural phenomena and spaces outside of traditional forms of religion also aid in this religious and spiritual exploration. This corresponds with Hutch (2012) premise that we should seek to "articulate the lived experiences of the individual, notwithstanding the presence or absence of a commitment to a particular set of religious beliefs and practices" (p. 141). In other words, religious beliefs and practices, and in this case, religious deconversion, exist alongside various other lived experiences. People are continuously assessing and integrating these experiences to formulate subjectivities, positions, and perspectives. This is a generally shared reality beyond the Southern milieu. More work needs to be conducted to assess the particulars of deconversion in other areas of the United States and beyond that can incorporate the privatization of religion for the health of relational networks, the navigation of increasingly pluralistic ideas and perspectives, and modes of patriotism.

The sample size of this study is too small to make any substantial inference. What the data do suggest is that sport can play an integral role in the deconversion processes and, for some individuals in the South, sport aids in filling particular relational voids. Individuals on deconversion journeys in the modern Bible Belt are not constrained by the boundaries of religious institutions or traditions. As lives are reconstructed, individuals discover resources for reconstituting their Self. These resources are typically understood as having a sacred quality for those individuals. In this case, this reconstitution work includes mining the past to question where it all began, reflecting on how the present conditions are ameliorated or on future oriented methods of challenging the structural systems. In each of these realms, sport can be a contributing space for discovering rehabilitative hope in these situations.

These individual deconversion changes reflect broader social transformation in the Bible Belt culture. In the American South, change has been viewed with intense suspicions. Yet, like the rest of the country, the Bible Belt is experiencing transformations in various sectors of life like economics, demographics, and religion. Many Southerners attempt to resist these changes and seek to rediscover an ever-disappearing past. However, these "efforts to insist on a return to traditional pieties thus inevitably clash with the structure of the modern economy and produce recurring cries of moral crisis" (Cahn and Carbone 2010). The moral crises are typically articulated in religious and political spaces in the South. Sport, especially college sports, currently remains unscathed from the moral crisis discourse. In this way, sport offers a safer space for families and friends to maintain their relationships and broaden their social networks.

Moreover, the South is still plagued by racialized structures. Religious communities, broadly speaking, have failed to racially integrate society and help move the Bible Belt forward in a healthier, racially integrated direction. Churches are typically still racially segregated, but college sports, which are extremely important for many Southerners, offer an opportunity for more racial and gender integration due to Title IX mandates. In this way, secularized, college sporting institutions serve as a model for those deconverting to more progressive forms of religiosity and spirituality.

Southerners also seek mechanisms by which to transmit their heritage to their children and grandchildren. Whereas the local church has been central in these endeavors in the past, today many Southern families simply do not share religious values, ideas, or institutions. This forms a need to seek other avenues for cultural transmission. Sport is one site displacing religion in this way. Sport offers a way of transmitting shared values like team fandom, identities, and practices. This assuages the loss of common religiosity and family fracturing due to this loss. In other words, where religion serves as a site for familial conflict, sport tempers this reality and offers a way to connect and pass on heritage. In a previous work, I described sport as an institutional "mason jar" that preserves the ethos and pathos of Southern culture (removed for peer review). In this way, sporting commitments might become increasingly important in the future of the South.

Yet, the mason jar strength of Southern sport could be jeopardized by athletic activism. This is neither a defense nor a critique of athlete activism, but more a point of how activism by athletes, whether college or professional, could disrupt how sport is utilized as a rehabilitative hope. If sport becomes politicized, then the personal aspects of remediation might fade. Many Southerners would 
understand athletic activism as a corruption of the purity of the athletic fields and courts. This only serves to support the notion that in the Southern mind, sport possesses a sacred quality that is separate from the mundane sector of politics.

As the United States continues to modernize and secularize, regional identities are becoming less distinct. With increase access to mobilization, fewer people remain anchored geographically. These relocations pluralize regions, creating a new heterogeneity. In order for the regional identity of "Southerners" to proceed into the future, enough shared common interests in perpetuating the regionalism must exist. It is my argument herein that sport is the site for this regional cultivation and perpetuation. In fact, sport is a site for rehabilitative hope for Southerners today.

Funding: The research received no external funding.

Conflicts of Interest: The author declares no conflict of interest.

\section{References}

Allen, Barbara. 1990. The Genealogical Landscape and the Southern Sense of Place. In Sense of Place: American Regional Cultures. Edited by Barbara Allen and Thomas J. Schlereth. Lexington: The University of Kentucky Press.

Altglas, Veronique. 2014. 'Bricolage': Reclaiming a Conceptual Tool. Culture and Religion 15: 475-93. [CrossRef]

Bain-Selbo, Eric. 2012. Game Day and God: Football, Faith, and Politics in the American South. Macon: Mercer University Press.

Bain-Selbo, Eric, and D. Gregory Sapp. 2016. Understanding Sport as a Religious Phenomenon. London and New York: Bloomsbury Academic.

Bain-Selbo, Eric, and Terry Shoemaker. 2016. Southern reconstructing: Sport and the future of religion in the American South. In Sport and Religion in the Twenty-First Century. Edited by Brad Schultz and Mary Lou Sheffer. Lanham: Lexington Books.

Bartkowski, John P., and W. Bradford Wilcox. 2000. Conservative Protestant child discipline: The case of parental yelling. Social Forces 79: 265-90. [CrossRef]

Barton, Bernadette. 2011. 1CROSS + 3NAILS = 4GVN: Compulsory Christianity and Homosexuality in the Bible Belt Panopticon. Feminist Formations 23: 70-93. [CrossRef]

Barton, Bernadette. 2012. Pray the Gay Away: The Extraordinary Lives of Homosexuals in the Bible Belt. New York: New York University Press.

Berger, Peter. 2014. The Many Altars of Modernity: Toward a Paradigm for Religion in a Pluralist Age. Boston and Berlin: Walter de Gruyter.

Bielo, James. 2017. The Question of Cultural Change in the Scientific Study of Religion: Notes from the Emerging Church. Journal for the Scientific Study of Religion 56: 19-25. [CrossRef]

Bruner, Mark W., Shea M. Balish, Christopher Forrest, Sarah Brown, Kristine Webber, Emily Gray, Matthew McGuckin, Melanie R. Keats, Laurene Rehman, and Christopher A. Shields. 2017. Ties That Bond: Youth Sport as a Vehicle for Social Identity and Positive Youth Development. Research Quarterly for Exercise and Sport 88: 209-14. [CrossRef] [PubMed]

Cahn, Naomi, and June Carbone. 2010. Red Families v. Blue Families: Legal Polarization and the Creation of Culture. Oxford: Oxford University Press.

Chelladurai, Joe M., David C. Dollahite, and Loren D. Marks. 2018. The family that prays together ... : Relational processes associated with regular family prayer. Journal of Family Psychology 32: 849-59. [CrossRef]

Côté, Jean, and Jessica Fraser-Thomas. 2016. Youth involvement and positive development in sport. In Sport and Exercise Psychology. Edited by Peter R. E. Crocker. Toronto: Pearson, pp. 256-87.

Danso, Henry, Bruce Hunsberger, and Michael Pratt. 1997. The role of parental religious fundamentalism and right-wing authoritarianism in child-rearing goals and practices. Journal for the Scientific Study of Religion 36: 496-511. [CrossRef]

Davie, Grace. 1994. Religion in Britain since 1945: Believing without Belonging. Oxford and Cambridge: Blackwell.

Dollahite, David C., and Loren D. Marks. 2009. A conceptual model of family and religious processes in highly religious families. Review of Religious Research 50: 373-91. 
Dowland, Seth. 2011. War, Sports, and the Construction of Masculinity in American Christianity. Social Compass 5: 355-64. [CrossRef]

Drescher, Elizabeth. 2016. Choosing Our Religion: The Spiritual Lives of America's Nones. New York: Oxford University Press.

Emerson, Michael O., and Christian Smith. 2000. Divided by Faith: Evangelical Religion and the Problem of Race in America. Oxford: Oxford University Press.

Erickson, Karl, and Jean Côté. 2016. An Exploratory Examination of Interpersonal Interactions between Peers in Informal Sport Play Contexts. PLoS ONE 11: e0154275. [CrossRef]

Gershoff, Elizabeth Thompson, Pamela C. Miller, and George W Holden. 1999. Parenting influences from the pulpit: Religious affiliation as a determinant of parental corporal punishment. Journal of Family Psychology 13: 307-20. [CrossRef]

Giulianotti, Richard. 2011. Sport, peacemaking and conflict resolution: A contextual analysis and modelling of the sport, development and peace sector. Ethnic and Racial Studies 34: 207-28. [CrossRef]

Godina, Lidija. 2014. Religion and parenting: relationship ignored? Child E Family Social Work 19: 381-90.

Harrold, Philip. 2006. Deconversion in the Emerging Church. International Journal for the Study of the Christian Church 6: 79-90. [CrossRef]

Hoffman, Shirl James. 2010. Good Game: Christianity and the Culture of Sports. Waco: Baylor University Press.

Hutch, Richard. 2012. Sport and Spirituality: Mastery and Failure in Sporting Lives. International Journal of Practical Theology 5: 131-52. [CrossRef]

Jones, Robert P. 2014. Southern Evangelicals Dwindling-and Taking the GOP Edge with Them. The Atlantic, October. Available online: http://www.theatlantic.com/politics/archive/2014/10/the-shrinking-evangelicalvoter-pool/381560/ (accessed on 8 March 2019).

Jones, Robert P., and Daniel Cox. 2017. America's Changing Religious Identity: Findings from the 2016 American Values Atlas. Public Research on Religion Institute. Washington, D.C. Available online: https: //www.prri.org/wp-content/uploads/2017/09/PRRI-Religion-Report.pdf (accessed on 8 March 2019).

Lewis, Jerry M. 2007. Sports Fan Violence in North America. Lanham: Rowman \& Littlefield Publishers.

Lubans, David R., Philip J. Morgan, and Ann McCormack. 2011. Adolescents and school sport: The relationship between beliefs, social support and physical self-perception. Physical Education and Sport Pedagogy 16: 237-50. [CrossRef]

Majaro-Majesty, Henry. 2011. Ethnicity, conflict and peace building: Effects of European football support in Nigeria. Soccer \& Society 12: 201-11.

Marks, Loren D., Trevan G. Hatch, and David C. Dollahite. 2017. Sacred practices and family processes in a Jewish context: Shabbat as the weekly family ritual par excellence. Family Process 57: 448-61. [CrossRef]

Marti, Gerardo, and Gladys Ganiel. 2014. The Deconstructed Church: Understanding Emerging Christianity. Oxford: Oxford University Press.

McMullin, Steve. 2013. The Secularization of Sunday: Real or Perceived Competition for Churches. Review of Religious Research 55: 43-59. [CrossRef]

Meyer, Gregory D., Neeru Jayanthi, John P. Difiori, Avery D. Faigenbaum, Adam W. Kiefer, David S. Logerstedt, and Lyle J. Micheli. 2015. Sport specialization, Part I: Does early sports specialization increase negative outcomes and reduce the opportunity for success in young athletes? Sports Health 7: 437-42. [CrossRef]

Miller, Patrick B. 2002. The Manly, the Moral, and the Proficient: College Sport in the New South. In The Sporting World of the New South. Edited by Patrick B. Miller. Urbana and Chicago: University of Illinois Press.

Moody, Sarah, and Randall Reed. 2017. Emerging Christianity and Religious Identity. Journal for the Scientific Study of Religion 56: 33-40. [CrossRef]

Putnam, Robert. 2000. Bowling Alone: The Collapse and Revival of American Community. New York: Simon \& Schuster.

Rogers, Matt. 2012. Contextualizing Theories and Practices of Bricolage Research. The Qualitative Report 17: 1-17.

Shoemaker, Terry. 2019. The Prophetic Dimension of Sport. Cham: Springer International Publishing.

Simmons, Jason, and T. Christopher Greenwell. 2014. Differences in Fan-Family Conflict Based on an Individual's Level of Identification with a Team. Journal of Sport Behavior 37: 94-114.

Smith, Gregory, Alan Cooperman, Jessica Martinez, Elizabeth Sciupac, and Conrad Hackett. 2015. America's Changing Religious Landscape. Pew Research Center. Available online: https://www.pewforum.org/2015/ 05/12/americas-changing-religious-landscape/ (accessed on 8 March 2019).

Stark, Rodney, and Roger Finke. 2000. Acts of Faith. Berkeley and Los Angeles: University of California Press. 
Thompson, Tracy. 2013. The New Mind of the South. New York: Simon \& Schuster.

Wann, Daniel L., Paula J. Waddill, Danielle Bono, Holly Scheuchner, and Kristen Ruga. 2017. Sport Spectator Verbal Aggression: The Impact of Team Identification and Fan Dysfunction on Fans' Abuse of Opponents and Officials. Journal of Sport Behavior 40: 423-43.

Wilson, Charles Reagan. 1980. Baptized in Blood: The Religion of the Lost Cause 1865-1920. Athens: University of Georgia Press.

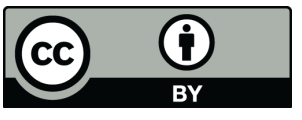

(C) 2019 by the author. Licensee MDPI, Basel, Switzerland. This article is an open access article distributed under the terms and conditions of the Creative Commons Attribution (CC BY) license (http://creativecommons.org/licenses/by/4.0/). 